\title{
Management of Hazardous Electronic Waste
}

\author{
Mamta Gupta \\ Junior Engineer \\ Power Development Dept \\ Jammu (J\&K), INDIA
}

\begin{abstract}
Waste Electrical and Electronic Equipment (WEEE) or EWaste, the most rapidly growing waste globally refers to obsolete, unwanted Electrical/Electronic devices that have reached end of life. WEEE contains more than 1000 different substances which fall under 'hazardous' and 'non-hazardous' categories. Broadly it consists of plastics, glass, printed circuit boards, ceramics, rubber, ferrous and non-ferrous metals, elements like lead, mercury, cadmium, silver, gold, platinum etc. Recycling of e-waste involves toxic processes such as open burning of Poly Vinyl Chloride (PVC) wires, acid bath, use of chemicals such as Mercury and Cyanide, heating of lead solders, etc. $95 \%$ of this waste is headed towards urban slums of developing countries like India and china for disassembly by a very well networked informal sector. The informal sector is characterized by small-scale, labourintensive, largely unregulated and unregistered, lowtechnology manufacturing or provision of services. In the context of municipal solid waste management (MSWM), the informal recycling sector workforce includes scavengers and waste pickers. Since the informal sector operates without any government intervention, people from the lower strata of society employed in these recycling units are prone to various health problems due to lack of protection (no masks, no gloves).
\end{abstract}

\section{Keywords}

Electronic waste, emissions, policies, recycling

\section{INTRODUCTION}

Electrical/Electronic devices that have reached their end of life are referred as E-Waste. It can be categorized into three main categories:

- Large Household Appliances - Refrigerators, Washing Machines etc.

- It \& Telecom Equipment - PCs, Monitors, Laptops etc.

- $\quad$ Consumer Equipments - TVs

WEEE contains more than 1000 different substances which fall under 'hazardous' and 'non-hazardous' categories. Broadly it consists of plastics, glass, printed circuit boards, ceramics, rubber, ferrous and non-ferrous metals, elements like lead, mercury, cadmium, silver, gold, platinum etc. The presence of elements like lead, mercury, palladium etc. beyond threshold quantities classifies the E-Waste as hazardous.

As per United Nations Environment Programme (UNEP) report, by the year 2020, E-Waste may rise by $500 \%$ from old computers; no. of discarded refrigerators will get doubled or tripled while the rate of discarding mobile phones will be 18 times higher as compared to 2007 levels.
In order to avoid high cost of E-Waste treatment and disposal, developed countries like USA, UK and Japan have been trying to send such waste overseas to developing countries like India, China and Africa. [1]

\section{CURRENT HANDLING OF E-WASTE}

$95 \%$ of this hazardous waste is processed and recycled by an informal sector, characterized by small-scale, labourintensive, largely unregulated and unregistered, lowtechnology manufacturing or provision of services. Such enterprises do not pay taxes, have no trading license and are not included in social welfare or government insurance schemes. In the context of municipal solid waste management (MSWM), the informal recycling sector refers to the waste recycling activities of scavengers and waste pickers.

Informal waste recycling is carried out by poor and marginalized social groups who resort to scavenging/waste picking for income generation and some even for everyday survival. This is widespread throughout urban areas of the developing world and it is reported that up to $2 \%$ of the population in Asian and Latin American cities depend on waste picking to earn their livelihood. Application of inefficient and non scientific methods increases the risk of environmental and occupational hazards. Samples collected from and around recycling facilities available in India at Seelampur, Jafrabad, Shastri Park, Mayapuri, Burari and adjoining areas of Delhi establish that lead, cadmium, acids and organic contaminants were being released into the environment.

According to Toxics Link, more than 10,000 people-again, including children-work in the "informal" recycling industry in Delhi alone, breaking equipment; using acid baths; and openly burning wires and plastic casings to reclaim gold, copper, and other valuable materials..

Since the informal sector operates without any government intervention, people from the lower strata of society employed in these recycling units are prone to various health problems due to lack of protection (no masks, no gloves). Long-term exposure to metals like lead, cadmium, chromium, mercury and polyvinyl chlorides (PVC) can severely damage the nervous systems, kidney and bones, and the reproductive and endocrine systems, and some of them are carcinogenic and neurotoxin. [2], [3]

\section{HOW CURRENT PRACTICES EFFECT HEALTH \& ENVIRONMENT?}

Inappropriate recycling generates significant hazardous emissions, with severe impacts on health and environment. In this context, three levels of toxic emissions have to be distinguished:

- Primary emissions: Hazardous substances that are contained in e-waste (e.g. lead5, mercury, arsenic, 
polychlorinated biphenyls (PCBs), fluorinated cooling fluids etc.).

- Secondary emissions: Hazardous reaction products of e-waste substances as a result of improper treatment (e.g. dioxins or furans formed by incineration/inappropriate smelting of plastics with halogenated flame retardants).

- Tertiary emissions: Hazardous substances or reagents that are used during recycling (e.g. cyanide or other leaching agents, mercury for gold amalgamation) and that are released because of inappropriate handling and treatment.
Table 1 \& Table 2. list the health and environment risks associated with informal recycling. They include occupational health risks posed to scavenger/waste pickers and community health risks posed to the related community or general public. These risks can originate from the nature of the waste or the process of collecting, processing, recycling and disposing of it. Informal waste pickers are undoubtedly exposed to increased risks as basic principles of occupational health and safety are disregarded. Scavenging in open dumps is considered to be the most detrimental to health.

Table 1. Health Effects

\begin{tabular}{|c|c|c|}
\hline Source of e-wastes & Constituent & Health effects \\
\hline $\begin{array}{l}\text { Solder in printed circuit boards, } \\
\text { glass panels and gaskets in } \\
\text { computer monitors }\end{array}$ & Lead $(\mathrm{Pb})$ & $\begin{array}{l}\text { - Damage to central and peripheral nervous systems, blood systems } \\
\text { and kidney damage. } \\
\text { - Affects brain development of children. }\end{array}$ \\
\hline $\begin{array}{l}\text { Chip resistors and } \\
\text { semiconductors }\end{array}$ & Cadmium $(\mathrm{Cd})$ & $\begin{array}{l}\text { - } \\
\text { - } \\
\text { - } \\
\text { - } \\
\text { - } \quad \text { Texic irrevers neuratogeniales in kidney and liver. }\end{array}$ \\
\hline $\begin{array}{l}\text { Relays and switches, printed } \\
\text { circuit boards }\end{array}$ & Mercury (Hg) & $\begin{array}{l}\text { - } \quad \text { Chronic damage to the brain. } \\
\text { - } \quad \text { Respiratory and skin disorders due to bioaccumulation in fishes. }\end{array}$ \\
\hline $\begin{array}{l}\text { Corrosion protection of } \\
\text { untreated and galvanized steel } \\
\text { plates, decorator or hardner for } \\
\text { steel housings }\end{array}$ & $\begin{array}{l}\text { Hexavalent } \\
\text { chromium (Cr) VI }\end{array}$ & $\begin{array}{l}\text { - } \\
\text { - } \\
\text { DNthmatic bronchitis. } \\
\text { DNA damage. }\end{array}$ \\
\hline Cabling and computer housing & $\begin{array}{l}\text { Plastics including } \\
\text { PVC }\end{array}$ & $\begin{array}{ll}\text { - } & \text { Burning produces dioxin. It causes } \\
\text { - } & \text { Reproductive and developmental problems; } \\
\text { - } & \text { Immune system damage; } \\
\text { - } & \text { Interfere with regulatory hormones }\end{array}$ \\
\hline $\begin{array}{l}\text { Plastic housing of electronic } \\
\text { equipments and circuit boards. }\end{array}$ & $\begin{array}{l}\text { Brominated flame } \\
\text { retardants (BFR) }\end{array}$ & - Disrupts endocrine system functions \\
\hline Front panel of CRTs & Barium (Ba) & $\begin{array}{l}\text { - } \quad \text { Short term exposure causes: } \\
\text { - } \quad \text { Muscle weakness; } \\
\text { - } \quad \text { Damage to heart, liver and spleen. }\end{array}$ \\
\hline Motherboard & Beryllium (Be) & $\begin{array}{l}\text { - } \quad \text { Carcinogenic (lung cancer) } \\
\text { Inhalation of fumes and dust. Causes chronic beryllium disease or } \\
\text { beryllicosis. } \\
\text { Skin diseases such as warts. }\end{array}$ \\
\hline
\end{tabular}


Table 2. Environment Effects

\begin{tabular}{|c|c|c|}
\hline Source Of E waste & Process Followed & Environmental Hazard \\
\hline $\begin{array}{lll}\begin{array}{l}\text { Cathode } \\
\text { (CRTs) }\end{array} & \text { Ray } & \text { Tubes } \\
\end{array}$ & $\begin{array}{l}\text { Breaking, Removal Of } \\
\text { Copper yoke and dumping }\end{array}$ & $\begin{array}{l}\text { - Heavy metals like Lead, Barium leach into ground water and } \\
\text { release toxic phosphor }\end{array}$ \\
\hline Printed Circuit Boards & $\begin{array}{l}\text { Desoldering and removing } \\
\text { chips }\end{array}$ & $\begin{array}{l}\text { - Brominated dioxins, berrylium, cadmium and mercury are } \\
\text { emitted in the air }\end{array}$ \\
\hline $\begin{array}{l}\text { Chips and other gold } \\
\text { plated compounds }\end{array}$ & $\begin{array}{l}\text { Chemical stripping using } \\
\text { nitric and hydrochloric acids } \\
\text { along river banks }\end{array}$ & $\begin{array}{l}\text { - Hydrocarbons dischrched directly into water acidifies the } \\
\text { river destroying fish and flora }\end{array}$ \\
\hline $\begin{array}{l}\text { Plastics from computer } \\
\text { and peripherals }\end{array}$ & $\begin{array}{l}\text { Shredding and low } \\
\text { temperature melting }\end{array}$ & $\begin{array}{ll}\text { Emission of brominated dioxins, heavy metals and } \\
\text { hydrocarbons in air }\end{array}$ \\
\hline $\begin{array}{l}\text { Dismantled printed circuit } \\
\text { board processing }\end{array}$ & $\begin{array}{l}\text { Open burning of waste } \\
\text { boards }\end{array}$ & - $\quad$ Tin and lead contamination of immediate environment \\
\hline Wires & $\begin{array}{l}\text { Open burning to recover } \\
\text { copper }\end{array}$ & $\begin{array}{l}\text { - Hydrocarbons and asshes including PAHs discharged into } \\
\text { air, water and soil. }\end{array}$ \\
\hline
\end{tabular}

In order to cater to this emerging problem, some authorized recycling companies have come up in India in the last few years like Attero Recycling Plant - Roorkee, Ash Recyclers Banglore, E Waste Agency (EWA) - Banglore etc. In such centres, heavy metals are safely extracted in a plant and everything else is recycled. But the irony is the authorized ewaste recycling facilities in India capture only $3 \%$ of the total e-waste generated; the rest makes its way to informal recycling yards in major cities like Delhi, Mumbai, and Bangalore. This is because businesses sell their discarded IT and other equipment to informal recyclers for quick money without realizing the hazardous implications it has on health and environment. [4]- [9]

\section{DISCUSSION - STEPS OF ACTION REQUIRED}

Introducing a legal industrial set-up for disposal and recycling of E-Waste would not only remove the threat to environment and public health but also generate an opportunity of employment. The e-waste (Management \& Handling) Rules, 2011 have been notified in May 2011 and made effective from 01-05-2012. These rules have been notified with primary objective to channelize the E-waste generated in the country for environmentally sound recycling. [11]

For the purpose, consumer-manufacturer collaboration is the key.

- Awareness Building -Working Groups comprising Regulatory Agencies, NGOs, Industry Associations, experts etc are required to create awareness among consumers regarding the potential threat to public health and environment by electronic products, if not disposed properly In order to dispose E-Waste scientifically, partnerships of municipal bodies with manufacturers and retailers can help in starting recycling services. Government should promote Information, Education and Communication (IEC) activities in schools, colleges, industry etc. to enhance the knowledge base on E-waste management.

- Policy Level Interventions - An integrated IT waste management policy is the need of hour. A separate set of rules need to be implemented to control the processes.

$>$ E-Waste Assessment should be carried out at national level with the help of state municipal bodies.

D Establishment of E-Waste collection, exchange and recycling centers should be encouraged in partnership with private entrepreneurs.

$>$ Categorization of E-Waste components for testing and separation of harmful materials is required so that effective precautionary measures should be taken to save the environment

$>$ Regulations for ensuring occupational health safety norms for the current informal sector of E-waste recycling can prevent the work force from severe health hazards. 
- Restructuring Recycling - Most of the current processes followed for recycling need improvement while some need to be abolished due to severe risks for health and environment Technical intervention must be sought for creating electronic components and peripherals of bio degradable material.

- Take Back Policies -Under Extended Producer Responsibility (EPR) approach, the global brands using developing countries as markets for the sale of their products should be compelled to start Take Back services also. End of life Management has to be a priority for companies putting new electronic products in market. [10],[11]

\section{CONCLUSION}

Though the growing E-Waste Management happens to be a big challenge but if tackled judiciously it can turn into an opportunity. Recovering valuable resources from $\mathrm{E}$ waste can help in setting up a new employment sector in the country. Proper e-waste management, from efficient sourcing and collection right up to extraction and disposal of material, has ensured that this huge pile of junk turns into a lucrative business opportunity. But the benefits can only be taken if the conventional methods pave way for scientific recycling of EWaste to avoid environmental and occupational hazards.

The legal framework provided by the government would enhance the growth opportunities in this sector.

\section{REFERENCES}

[1] Environment Alert Bulletin. "E Waste. The hidden side of IT equipment's manufacturing and use", 2004

[2] KURIAN JOSEPH (2007). "ELECTRONIC WASTE MANAGEMENT IN INDIA- ISSUES AND STRATEGIES"
[3] ROCHAT D, RODRIGUES W, GANTENBEIN A (2008). "INDIA : INCLUDING THE INFORMAL SECTOR IN A CLEAN E_WASTE CHANNEL"

[4] Ajeet Saoji, Associate Professor, Department of Community Medicine, NKP Salve Institute of Medical Sciences and Research Centre, Nagpur

"E-WASTE MANAGEMENT: AN EMERGING ENVIRONMENTAL AND HEALTH ISSUE IN INDIA"

[5] STEP Sustainable Innovation and Technology Transfer Industrial Sector Studies. "RECYCLING - FROMEWASTE TO RESOURCES”

[6] John B. Stephenson, Director, Natural Resources and Environment (2008) "ELECTRONIC WASTE: Harmful U.S. Exports Flow Virtually Unrestricted Because Of Minimal EPA Enforcement and Narrow Regulation"

[7] Vlolet N. Pimto, Department Of Community Medicine \& Dr.D.Y.Patil, Medical College and Hospital, Nerul, Navi Mumbai "E-waste Hazard: The Impending Challenge"

[8] Anwesha Borthakur, Pardeep Singh "Electronic waste in India: Problems and policies"

[9] Lakshmi Raghupathy, Ministry of Environment\& Forests, New Delhi (INDIA) "E-WASTE MANAGEMENT IN INDIA"

[10] EMPA. "MODELS FOR E WASTE MANAGEMENT"

[11] Central Pollution Control Board Hazardous Waste Management Division 'PariveshBhawan', East Arjun Nagar, Shahdara, Delhi - 110032 "Implementation of EWaste Rules 2011 Guidelines" 